\title{
China and the UN Food System Summit: Silenced Disputes and Ambivalence on Food Safety, Sovereignty, Justice, and Resilience
}

\author{
Li Zhang ${ }^{1}$
}

Published online: 20 October 2021

(c) Society for International Development 2021

\begin{abstract}
China is a major agricultural power. It dramatically reduced hunger and increased its role in many forums for international governance. However, the Chinese government and society neither played a prominent role in the UNFSS nor in its critique. This article exposes how tensions and ambivalence about agroecology and food sovereignty in China create silences in these discussions, and addressing them within China can also resolve the global tensions that marked the UNFSS as a whole.
\end{abstract}

Keyword Agroecology $\cdot$ Neo-Malthusianism $\cdot$ Ecomodernization $\cdot$ Public health

China is the world's second largest economy. It has the largest total agricultural output on the planet and became the world's top agricultural importer in 2020. Its record-breaking urbanization created almost 850 million urban food consumers, while it still maintains almost 560 million people in the countryside, mostly engaged in small-scale farming and livestock production. China has made remarkable progress in poverty alleviation and eradicated famine, yet 150 million people still suffer from malnutrition. Moreover, China now also suffers a dramatic rise in diabetes, heart disease, and other nutrition-related chronic disease epidemics, unfolding alongside an intractable food safety crisis that undermines consumer trust even in certified organic produce. Moreover, while far-right nationalists in the US, India, Brazil, and beyond pull back from international and multilateral governance institutions, reducing their traditional influence over international food and agricultural policy, China has stepped in more clearly and forcefully across various fields of global governance. It would seem only natural that China would play a prominent and influential role in the UN Food System Summit (UNFSS) of 2021. However, China's contributions have been remarkably subdued, whether in the official channels of the UN or among the many critics who boycotted the Summit, organized the Autonomous People's Response to the UNFSS, and who are now reflecting critically about the

Li Zhang

li.zhang@uci.edu

1 Department of Global and International Studies, University of California, Irvine, CA, USA process. In this article, I briefly outline China's contributions to the UNFSS, and identify key themes in the current politics of food systems in China and their links with larger global processes. I argue that understanding the silences in China's national dialogue in the UNFSS framework help us understand the tensions in China's contemporary food system, and addressing the silences in these discussions within China can also be instrumental to resolve the global tensions that marked the UNFSS as a whole.

\section{China in the UNFSS}

The Chinese government nominated a Convener to the Food System Summit Dialogues, submitted a brief 3-page presummit statement outlining its achievements in food security and poverty alleviation and its priorities for agricultural modernization, and a prominent Chinese agricultural economist was included among the 28 members of the Scientific Group of the UNFSS. The Vice Minister of Agriculture and Rural Affairs convened a National Dialogue in April 2021, attended by 107 participants from nearly all sectors of China's food system. The Dialogue was centered on ten keynote presentations, combined with five 'open discussions' on themes that overlap with but don't necessarily follow the structure of the UNFSS five 'action tracks'. These topics were: (1) food system transformation and policy support, (2) food production and sustainable development, (3) food loss and shock response, (4) food security and equitable livelihoods, and (5) sustainable food consumption. The dominant 
voices in the National Dialogue were from its best represented stakeholders: 33 participants from the UN and Chinese government institutions, and another 20 from scientific research institutions and universities. Small-scale farmers and ethnic minorities were represented by 16 individuals, while five represented consumer groups, four represented Chinese NGOs, and two represented workers. Chinese and multinational agribusiness corporations, international financial institutions, medium- and large-scale farmers, and private foundations were also represented by 14 individuals.

The UNFSS agenda for discussion is so contentions that hundreds of scientists, civil society organizations and rural social movements from around the world actively boycotted the UNFSS and led a People's Autonomous Response that is highly critical of the UNFSS and the entire framework of its preparations. Despite including so many stakeholders in its National Dialogue, however, the Chinese official feedback form from its event included a single word in the section on 'Areas of Divergence: None' (Food Systems Summit 2021: 12). It is difficult to imagine such absolute consensus among so many stakeholders, and it is easy to chalk this is up simply as the result of an authoritarian state and society. However, the reality is more complex, as the silenced disputes do not simply mask a 'quiet social movement' for food sovereignty in China, but also emerge from deep ambivalence among most stakeholders regarding the root causes and necessary solutions to the food safety crisis, competing understandings of food security and food sovereignty, and the sacrifice of public health and environmental justice in the name of a depoliticized interpretation of resilience (Zhang and Qi 2019; Zhang 2020). A similar dynamic was witnessed during the International Assessment of Agricultural Knowledge, Science and Technology for Development (IAASTD) from 2005 to 2008, an international effort led by the World Bank in collaboration with the Food and Agriculture Organization (FAO) and various UN organizations. The IAASTD came out forcefully in favor of agroecology and food sovereignty and the Chinese government ratified the agreement. Yet, Chinese food and agrarian development policy continues to ignore the tension between the food sovereignty and food security frameworks, and contradictions between labourintensive agroecology and scaling up agro-industrialization. The implicit idea is that these are technical issues that can coexist or even be combined for sustainable development, rather than power-infused political economic conflicts that pertain to control over labour, resources, markets, and profits.

This depoliticized approach to both the IAASTD and the National Dialogue is deeply rooted in a neo-Malthusian framework that frames China's food system primarily in terms of 'resource constraints', particularly a 'lack of sufficient arable land and water resources', aggravated by climate change and stress on food supply due to 'population growth and rising urbanization' (Food Systems Summit 2021: 6). Changes in demand are expressed as a shift among consumers from 'mere food sufficiency' towards a desire for 'nutrition, health benefits, and safety from foods'. Presented as an undeniable fact of biophysical constraints and rising incomes, stakeholders in these forums are forced to accept the imperative to increase output through 'intensification', yet no space was made to discuss the differences between labour-intensive agroecological intensification and capitalintensive agroindustrial intensification. Discussion of solutions at the National Dialogue was largely contained within the parameters of ecomodernization theory, as smallholders were recognized to be 'vulnerable' in the increasingly commodified food system, but their vulnerability was largely characterized as 'suffer[ing] from adverse selection due to information asymmetry', rather than power imbalances from increasingly dramatic socio-economic inequalities in access to land, capital, and public resources (Food Systems Summit 2021: 6, emphasis added). Therefore, concerns about equitable livelihoods were largely envisioned in terms of improving e-commerce to increase 'market access' for small farmers, while the main thrust of the Dialogue's recommendations focused on guaranteeing food security through reforms in rural land system and increased investments in agricultural technology to 'expand the scale of production' (Food Systems Summit 2021: 7, 10).

The Chinese government officials and scholars who promote this vision sincerely believe this is the way to rescue China's peasants from poverty and backwardness. However, even though a few of the most well capitalized peasants might be able to become successful agrarian capitalists, this process of increasing output by scaling up production effectively marginalizes the majority, while increasing dependence on chemical fertilizers and toxic pesticides that undergird China's food safety crisis (Zhang and Qi 2019). Despite the global agroecology and food sovereignty movement drawing extensively from traditional knowledge of Chinese peasants and the powerful example of the peasant-led communist revolution in China, the words 'agroecology' and 'food sovereignty' are not featured anywhere in the report.

The deep ambivalence about peasant-led food sovereignty and agroecology in the Chinese context is illustrated by the way the Dialogue's discussion of food production and sustainable development emphasized 'waste recycling', and an entire discussion topic centered upon 'post-harvest food loss' as the key issue in shock response. This discussion could present an opportunity to critique the industrialization of livestock production. After all, livestock are now the main factor causing water pollution (pig and poultry waste from concentrated animal feeding operations, CAFOs) and driving the bulk of China's demand for agricultural imports. Moreover, the rapid concentration of livestock is increasing the risk of pandemics, including both livestock diseases like 
the African Swine Fever (ASF) pandemic that killed nearly half of China's pigs between 2018 and 2019, and the recurring emergence of zoonotic diseases like influenza, SARS and COVID-19 (Schneider 2017; Zhang 2021a).

Strengthening small-scale livestock production in diversified farming systems is the cornerstone of peasant agriculture in China, and it rests entirely on recycling the waste from livestock (who in turn consume household and postharvest waste in the countryside) as non-commercial and organic fertilizer. Yet the report on waste recycling and postharvest food loss focused again on e-commerce 'to standardize farm production and marketing activities' (Food Systems Summit 2021: 9). Rather than recognizing the potential of peasant agroecology to reduce China's food waste problem while strengthening food sovereignty through a reduced dependence on chemical fertilizers and imported livestock feed, 'sustainable development' was framed instead by an ecomodernist assumption that more technology alone can reduce waste by increasing the commodification of China's food and farming, increasing the power and profits of China's e-commerce and agribusiness corporations even as it continues to marginalize the majority of peasants who form the backbone of China's food system.

Moreover, even when the terms 'agroecology' and 'food sovereignty' are used in China, discussion is deeply ambivalent, as the terms are usually depoliticized and treated as interchangeable with 'sustainable agriculture' and 'food security' or even near self-sufficiency in domestic 'grain security' (Zhang 2021b). The result is that the fifth and final topic for discussion at China's National Dialogue explicitly decentered a producer-based framework of food sovereignty and agroecology to promote instead 'sustainable food consumption', based upon technology innovation in food processing and the education of consumers about food nutrition and recycling of consumer products (Food Systems Summit 2021: 11). This ambivalence explains why Chinese government officials and influential voices among its scientific community and agribusiness sector were content with the platitudes expressed about 'sustainable development' in the UNFSS, overlooking entirely the international critiques centered upon the People's Autonomous Response to the UNFSS, and feeling no need to engage beyond their own National Dialogue in any of the three stages for dialogue orchestrated by the Summit. This single official feedback form submitted, for example, stands in sharp contrast with some of its neighbors who featured among the most prominent participants in the UNFSS, including Japan (which submitted 45 reports), Cambodia (28 reports), Philippines (12 reports), Nepal (10 reports), Mongolia (9 reports), and
South Korea (6 reports). ${ }^{1}$ China is well positioned to play a much more meaningful role in international food system governance, but for better or worse that is prevented by the tensions within China's own domestic politics towards food, agrarian, environmental, and public health governance.

\section{Contemporary Politics of Food Systems in China and the World}

Three key themes characterize the contemporary politics of food and agriculture in China and its articulations with global food systems. First, there is a tension between food security and food safety. The government, leading scientific institutions, and a range of investors from urban entrepreneurs to major corporations become increasingly allied in efforts of poverty alleviation through industrializing and scaling-up production, intended to guarantee food security by increasing supply. Yet this process deepens the commodification of food and farming, increasing dependence on mechanization, toxic agrochemicals, and food processing. This promotes the interest of agribusiness investors over peasant producers, who are displaced or subjected to adverse incorporation in production chains that extract value from the countryside and concentrate wealth among agribusiness corporations. Consequently, peasants seek selfprotection by adopting a 'one family, two systems' production practice, maintaining limited organic food production for domestic consumption, while relying upon toxic agrochemicals to increase output of cash crops for the market. In turn, health-conscious urban consumers are attempting to establish 'alternative food networks' (AFNs) to access safer organic foods, as mainstream food supplies continued to be plagued by recurrent food safety incidents. Yet AFNs can only attend niche markets for wealthy consumers, and this growing demand even creates problems of health and environmental justice, as peasant producers are increasingly commercializing their organic foods and turning instead to cheap processed foods for their own consumption. Rather than addressing the food safety crisis, therefore, mainstream efforts to modernize agriculture and food production increases food safety problems for the majority of the rural and urban poor, who are exposed to agrochemical intoxication and the perverse incentives for adulteration of processed foods (Yan 2015; Zhang and Qi 2019; Zhang 2021b). This process is not exclusive or limited to China, of course, as the world's leading agrochemical companies and food processors now feature Chinese corporations among their ranks,

\footnotetext{
${ }^{1}$ Member State Dialogues Synthesis Report 3, September 2021. Annex A - Official Feedback Forms published by Member State Convenors. UNFSS.
} 
which reproduce domestically a tension that characterizes global food systems.

Second, there is a tension between the modernization of agricultural production and food supply networks and the need to safeguard rural livelihoods. Government and corporate interests combine efforts towards 'rural vitalization' because the four decades of market-oriented reforms have caused a dramatic rural exodus, as peasants become migrant workers and China's villages become 'hollow', inhabited primarily by so-called 'left behind women' who remain in the countryside to farm and care for the elders and children who cannot go work in urban industries or access social services in the cities. Efforts to address the plight of these so-called 'left behind' populations usually encompass their organization into cooperatives that can partner with agribusiness investors and e-commerce companies. Yet this process ultimately relies upon further commodification of food and farming, and policy incentives enable elite-capture of cooperatives, which leads to the marginalization and displacement of peasants by larger-scale producers and global agribusiness corporations. Efforts to sustain agroecology and organic food production by protecting heirloom seeds and local varieties of livestock, which are largely led by female peasants, scholars, and NGO organizers, provide the most fruitful framework for strengthening rural livelihoods, expressing the 'Chinese characteristics' of the global movement for food sovereignty (Zhang 2020; Yan et al. 2021).

Third and finally, there is a tension between agro-industrialization (particularly the modernization of the livestock industry and agri-food markets) and the need to prevent emerging diseases with pandemic potential. The fact that pandemic influenza, SARS, and COVID-19 emerge from increased exposures in the human-animal interface have placed wild animals and wet markets in the spotlight, leading the Chinese government and corporations in alliance with global scientific and economic institutions like the World Bank to promote biosecurity in wild animal production by industrializing this sector, and replacement of wet markets with supermarkets. Yet the industrialization of pork and poultry production shows that the large-scale concentration of genetically homogenous animals is actually the main factor creating conditions for the acceleration of virus mutations that can spill over and cause pandemics among humans. Yet Chinese government officials and scholars usually blame small scale producers, who they characterize as lacking biosecurity, as witnessed in the response to the ASF pandemic. But in fact, it is the replacement of small scale and decentralized livestock production by large-scale CAFOs that increases the risk and impact of pandemics among animals and humans alike. And just as with food safety incidents discussed above, the modernization of markets does not eliminate the risk of these spaces becoming major conduits for the spread of disease as well, as illustrated by the major outbreak of COVID-19 at the highly modern Xinfadi market in Beijing in the summer of 2020, well after the epidemic had already been contained domestically (Wallace 2016; Zhang 2021a.)

\section{Conclusion}

The three themes that characterize domestic food politics in China bring us back full circle to the silenced disputes and ambivalence witnessed at the National Dialogue in China for the UNFSS. The food safety crisis, decline in rural livelihoods, and disruptions to China's food supply chain due to disease outbreaks all combine in the need to increase supply chain resilience to various political, economic, and ecological shocks, such as those resulting from the US-China trade war, catastrophic droughts and floods, and the current pandemic. In a global perspective, the disruption of China's food supply chains due to the sudden and rigorous lockdowns at the onset of the COVID-19 pandemic was dramatic, but short-lived because of the rapid and effective suppression of the disease domestically. Yet so long as resilience is envisioned through the flexible acquisition and distribution practices of e-commerce and major agribusiness corporations, rather than the sustainable livelihoods of peasants in diversified farming systems with agroecology, future shocks may continue to be well absorbed by corporate actors even while China's food sovereignty is increasingly eroded and undermined. The dialogue that China needs is not one that silences debate through neo-Malthusian fears and technological fetishism. Instead, it is necessary to confront the real tensions and contradictions in contemporary food politics in China, particularly the public health crises of food safety and zoonotic disease emergence, and the environmental injustice that blames the poor and marginalized peasants for these crises. After all, it is the Chinese peasantry that bears the worst effects of these crises, while also holding the best solutions for labour-intensive agroecology in diversified farming systems. Addressing the silences in these discussions within China can also be instrumental to resolve the global tensions that marked the UNFSS as a whole.

\section{References}

Food Systems Summit. 2021. Report of China's National Dialogue on Food Security and Sustainable Development for the United Nations Food Systems Summit, Food Systems Summit Dialogues Official Feedback Form, 23 July.

Schneider, Mindi. 2017. Wasting the rural: Meat, manure, and the politics of agro-industrialization in contemporary China. Geoforum 78: 89-97.

Wallace, Rob. 2016. Big Farms Make Big Flu: Dispatches on influenza, agribusiness, and the nature of science. New York: Monthly Review Press. 
Yan, Yunxiang. 2015. From Food Poisoning to Poisonous Food: The Spectrum of Food-Safety Problems in Contemporary China. In Re-Orienting Cuisine: East Asian Foodways in the Twenty-First Century, ed. Kwang Ok Kim, 263-286. New York: Berghahn Books.

Yan, Hairong, Ku Hok Bun, and Xu. Siyuan. 2021. Rural revitalization, scholars, and the dynamics of the collective future in China. Journal of Peasant Studies 48 (4): 853-874.

Zhang, Li. 2021a. The Origins of COVID-19: China and Global Capitalism. Palo Alto: Stanford University Press.

Zhang, Li. 2021b. The political ecology of maize in China: National food security and reclassification from staple to industrial crop. In The Political Ecology of Industrial Crops, ed. A. Ahmed and A. Gasparatos, 221-243. London: Routledge.
Zhang, Li. 2020. From left behind to leader: Gender, agency, and food sovereignty in China. Agriculture and Human Values 37 (4): 1111-1123.

Zhang, Li., and Gubo Qi. 2019. Bottom-up self-protection responses to China's food safety crisis. Canadian Journal of Development Studies 40 (1): 113-130.

Publisher's Note Springer Nature remains neutral with regard to jurisdictional claims in published maps and institutional affiliations. 